\title{
Abstrak \\ Hubungan Antara Skor IPSS Dengan Kualitas Hidup Penderita LUTS di Beberapa Puskesmas Kota Manado
}

\author{
Apriska Bassay, Alwin Monoarfa, Victor Pontoh \\ Bagian Bedah, Fakultas Kedokteran Universitas Sam Ratulangi \\ Email:apriskadebora@gmail.com
}

Purpose: To know the correlation between IPSS score with quality of life of LUTS patients. Background: Lower Urinary Tract Symptoms (LUTS) are a common problem in men that quite annoying and decreasing the quality of life with various micturition complaints.

Methods: This research methods using cross-sectional study which is conducted along November until December 2015 in some Clinics in Manado and founded 32 samples. Collected data technic is based on IPSS questionaire form. The Data Analysis using descriptive analysis for patient ditribution and correlation analysis with Rank Spearman test. Results: The Most insident of LUTS belonged to the age group of $60-69$ years old for 10 patients (32.3\%). The majority of respondents had moderate-severe degree of IPSS score (14 patients, 43,8\%). And that 14 patients (43,8\%) were not happy with their quality of life. The Rank Spearman correlation test showed there was a significant correlation $(\mathrm{p}<0,005)$ between the IPSS and quality of life, with score $r=0,578$.

Conclusion: There was a significant correlation between IPSS with quality of life of patients that most of LUTS patients in Manado seek medical threatment came with the severe degree with unhappy quality of life because their was low of economic and knowledge level about LUTS.

Keyword: LUTS, IPSS, Quality of Life

Tujuan Penelitian: Untuk mengetahui hubungan antara skor IPSS dengan kualitas hidup penderita LUTS.

Latar Belakang: Lower Urinary Tract Symptoms (LUTS) merupakan masalah umum pada pria yang cukup mengganggu dan menurunkan kualitas hidup penderitanya oleh karena berbagai keluhan miksi.

Metode Penelitian: Penelitian ini menggunakan metode cross-sectional pada bulan November-Desember 2015 dibeberapa Puskesmas Kota Manado dan didapatkan 32 sampel. Pengambilan data berdasarkan lembaran kuesioner IPSS. Data dianalisis menggunakan analisis deskriptif untuk distribusi penderita dan analisis korelasi dengan uji Rank Spearman.

Hasil: Insiden penderita LUTS terbanyak pada usia 60-69 tahun yaitu 10 penderita (31,3\%). Derajat LUTS yang sering dialami ialah derajat sedang-berat yaitu 14 penderita (43,75\%). Dan 14 penderita (43,8\%) merasa tidak nyaman dengan kualitas hidup. Pada uji korelasi Rank Spearman menunjukkan adanya hubungan bermakna $(\mathrm{p}<0,005)$ antara IPSS dengan kualitas hidup, dengan nilai $r=0,578$.

Kesimpulan: Adanya hubungan yang bermakna antara IPSS dengan kualitas hidup bahwa sebagian besar penderita LUTS berobat saat sudah masuk derajat berat dengan kualitas hidup tidak nyaman oleh karena pendidikan yang rendah dan berpenghasilan ekonomi dibawah ratarata.

Kata Kunci: LUTS, IPSS, Kualitas Hidup 


\section{PENDAHULUAN}

Lower Urinary Tract Symptoms (LUTS) adalah istilah umum yang menjelaskan berbagai gejala saluran kemih bagian bawah. Menurut International Continence Society (ICS), LUTS memberikan gejala obstruksi dan gejala iritasi. ${ }^{1}$ Banyak faktor yang dapat menyebabkan LUTS, salah satunya ialah hiperplasia prostat jinak (BPH). ${ }^{2}$ Hiperplasia prostat jinak didefinisikan sebagai proliferasi sel stroma pada prostat yang menyebabkan pembesaran pada kelenjar prostat. $^{3}$

Menurut survei Kesehatan Masyarakat di Boston (In Boston Area Community Health survey), kejadian LUTS meningkat dari $8 \%$ pada pria dengan usia 30-39 tahun hingga 35\% usia 60-69 tahun, $56 \%$ usia 70-79 tahun, 70\% usia 80-89 tahun dan mencapai $90 \%$ pada pria dengan usia 90 tahun. ${ }^{4}$ Telah dilaporkan bahwa $90 \%$ dari pria yang berusia 50 sampai 80 tahun menderita LUTS dengan prevalensi gejala penyimpanan meningkat $3 \%$ pada pria yang berusia 40 hingga 44 tahun dan menjadi $42 \%$ pada mereka dengan usia diatas 75 tahun. Satu studi menemukan bahwa prevalensi nokturia pada pria dengan usia di atas 85 tahun adalah sekitar $69 \%$ dibandingkan dengan $49 \%$ pada wanita. $^{5,6}$

Di Amerika Serikat hampir 1/3 laki-laki berusia 40-79 tahun memiliki gejala LUTS sedang sampai berat dengan penyebab utama adalah Hiperplasia Prostat. ${ }^{7}$ Penduduk Indonesia yang berusia tua jumlahnya meningkat, diperkirakan sekitar 5\% atau kiria-kira 5 juta pria di Indonesia berusia 60 tahun lebih dan 2,5 juta pria diantaranya menderita LUTS akibat hiperplasia prostat yang mempengaruhi kualitas hidup pada hampir $1 / 3$ populasi pria berusia $>50$ tahun. $^{8}$

LUTS merupakan masalah umum, terutama bagi pria usia lanjut. ${ }^{9}$ LUTS yang memberikan keluhan berupa sulit memulai miksi, pancaran miksi yang lemah, miksi terputus-putus, dan sering miksi dimalam hari dapat berdampak negatif terhadap kesehatan sehubungan dengan penurunan kualitas hidup penderita. ${ }^{10-12}$

Tidak semua pria usia lanjut merasa terganggu dengan LUTS dan akhirnya tidak mencari pengobatan medis. Menurut Nugroho (2002), keterlambatan deteksi dini dipengaruhi oleh persepsi penderita terhadap keluhan yang dirasakan dan sering diabaikan, sehingga keadaan tersebut dapat berpengaruh terhadap kualitas hidup penderita. Gejala yang timbul terus menerus dan dirasakan semakin mengganggu akan memotivasi penderita untuk pergi berkonsultasi pada tenaga medis dengan harapan gejala tersebut dapat teratasi.

Dengan kata lain, skor IPSS dan kualitas hidup berperan dalam penilaian dan rencana terapi LUTS. Maka peneliti ingin melakukan penelitian dengan metode cross-sectional untuk mengetahui hubungan antara skor IPSS dengan kualitas hidup penderita LUTS di beberapa Puskesmas Kota Manado.

\section{METODE PENELITIAN}

Penelitian ini merupakan penelitian bersifat analitik dengan menggunakan metode cross-sectional untuk mengetahui hubungan antara skor IPSS dengan kualitas hidup penderita LUTS. Penelitian ini dilakukan pada bulan November-Desember 2015, dan didapatkan 32 penderita LUTS yang memenuhi kriteria inklusi. Penelitian dilakukan di beberapa Puskesmas kota Manado antara lain Puskesmas Tuminting, Wonasa, Paniki, Bahu, dan Tikala Baru. Metode pengumpulan yang digunakan adalah non probability sampling yaitu dengan mengumpulkan penderita LUTS selama batas waktu yang ditargetkan dalam penelitian ini yakni 2 bulan (bulan November-Desember 2015). Kriteria inklusi dari penelitian ini adalah pria usia 40 tahun ke atas yang menderita LUTS yang bersedia ikut dalam penelitian serta menandatangani informed consent. Instrumen penelitian yang digunakan adalah lembar pertanyaan atau kuesioner 
International Prostate Symptom Score (IPSS) dan indeks Kualitas Hidup.

IPSS terdiri atas tujuh pertanyaan yang berhubungan dengan gejala LUTS yang masing-masing memiliki nilai 0 hingga 5 dengan total maksimum 35 dan satu pertanyaan mengenai kualitas hidup yang terdiri atas enam kemungkinan jawaban. LUTS dibagi atas derajat ringan (IPSS 0-7), derajat sedang (IPSS 8-19) dan derajat berat (20-35). Penilaian gejala LUTS dengan IPSS merupakan usaha penilaian secara objektif yang telah teruji, terbukti konsisten dan dapat dipercaya. Analisis data dilakukan dengan menggunakan analisis deskriptif untuk distribusi penderita LUTS dan analisis korelasi menggunakan uji korelasi Rank Spearman.

\section{HASIL PENELITIAN}

Berdasarkan penelitian cross sectional yang dilakukan di beberapa Puskesmas Manado antara lain Puskesmas Tuminting, Puskesmas Wonasa, Puskesmas Paniki, Puskesmas Tikala baru serta Puskesmas Bahu pada bulan November-Desember 2015, diperoleh data sebanyak 32 penderita LUTS yang sudah memenuhi kriteria inklusi, dan distribusinya dapat dilihat pada tabel 1.

Tabel 1.Distribusi Penderita Berdasarkan

\begin{tabular}{ccc} 
& Usia & \\
\hline Usia & Jumlah & $\mathbf{( \% )}$ \\
\hline $40-49$ & 3 & 9,3 \\
$50-59$ & 4 & 12,5 \\
$60-69$ & 10 & 31,3 \\
$70-79$ & 8 & 25 \\
$80-89$ & 6 & 18,8 \\
$\geq 90$ & 1 & 3,1 \\
\hline Total & $\mathbf{3 2}$ & $\mathbf{1 0 0}$ \\
\hline
\end{tabular}

Tabel 1 menunjukkan distribusi penderita LUTS berdasarkan usia antara 40 sampai dengan $\geq 90$ tahun yang datang di beberapa Puskesmas Kota Manado selama bulan November-Desember 2015, didapatkan golongan usia terbanyak berkisar antara usia 60-69 tahun yaitu 10 penderita (31,3\%), golongan usia 70-79 tahun yaitu 8 penderita (25\%), diikuti golongan usia 80-89 tahun sebanyak 6 penderita (18,8\%) dan golongan usia 50-59 tahun sebanyak 4 penderita (12,5\%), kemudian golongan usia 40-49 tahun sebanyak 3 penderita (9,3\%), dan golongan usia terendah pada usia $\geq 91$ tahun yaitu 1 penderita (3,1\%).

Tabel 2. Distribusi Penderita Berdasarkan Skor IPSS

\begin{tabular}{ccc}
\hline Skor IPSS & Jumlah & o) \\
\hline Ringan & 4 &, 5 \\
Sedang & 14 & 75 \\
Berat & 14 & 75 \\
\hline Total & $\mathbf{3 2}$ & $\mathbf{1 0}$ \\
\hline
\end{tabular}

Tabel 2 menunjukkan distribusi penderita berdasarkan derajat gejala yang dirasakan. Hasil yang didapatkan selama penelitian, bahwa penderita LUTS yang datang di beberapa Puskesmas Kota Manado terbanyak ditemukan dengan derajat IPSS yang berat yakni 14 penderita $(43,75 \%)$, diikuti dengan derajat IPSS sedang sebanyak 14 penderita (43,75\%), dan derajat ringan sebanyak 4 penderita $(12,5 \%)$.

Tabel 3. Distribusi Penderita Berdasarkan Skor Kualitas Hidup

\begin{tabular}{ccc}
\hline $\begin{array}{c}\text { Skor Kualitas } \\
\text { Hidup }\end{array}$ & Jumlah & $\mathbf{( \% )}$ \\
\hline Senang sekali & 0 & 0 \\
Senang & 1 & 3,1 \\
Pada umumnya & 5 & 15,6 \\
puas & & \\
Campur antara & 1 & 3,1 \\
puas dantidak & & \\
Pada umumnya & 5 & 15,6 \\
tidak puas & & \\
Tidak nyaman & 14 & 43,8 \\
Buruk sekali & 6 & 18,8 \\
\hline Total & $\mathbf{3 2}$ & $\mathbf{1 0 0}$ \\
\hline
\end{tabular}


Tabel 3 memperlihatkan distribusi penderita berdasarkan skor kualitas hidup menunjukkan bahwa 14 penderita (43,8\%) merasa tidak nyaman dengan kualitas hidupnya, diikuti dengan 6 penderita $(18,8 \%)$ yang merasa kualitas hidupnya buruk sekali, lalu terdapat 5 penderita (15,6\%) yang pada umumnya merasa puas dengan kualitas hidupnya, diikuti 5 penderita $(15,6 \%)$ yang tidak puas dengan kualitas hidupnya, kemudian terdapat 1 penderita $(3,1 \%)$ dengan kualitas hidup campur yakni puas dan tidak, dilanjutkan dengan 1 penderita (10,7\%) yang merasa senang dengan kualitas hidupnya, dan penderita yang senang sekali tidak ada (0\%).

Untuk melihat adanya hubungan antara skor IPSS dengan Kualitas Hidup maka digunakan uji korelasi Rank Spearman. Dari hasil Tabel 4, diperoleh hubungan yang signifikan ( $\mathrm{p}=0,001$ atau $(\mathrm{p}<0,005)$. Nilai korelasi Spearman sebesar 0,578. Hal ini menunjukkan bahwa adanya hubungan yang bermakna antara skor IPSS dengan skor kualitas hidup.

Tabel 4. Hasil uji hubungan skor IPSS dengan Kualitas Hidup penderita LUTS

\begin{tabular}{lllrr}
\hline \multicolumn{2}{c}{ Correlations } & Skor IPSS & Kualitas Hidup \\
\hline \multirow{4}{*}{ Spearman's rho } & \multirow{4}{*}{ Skor IPSS } & Correlation Coefficient & 1,000 &, $578^{* *}$ \\
& & Sig. (2-tailed) &. &, 001 \\
& & $\mathrm{~N}$ & 32 & 32 \\
& \multirow{4}{*}{ Kualitas } & Correlation Coefficient &, $578^{* *}$ & 1,000 \\
& Hidup & Sig. (2-tailed) &, 001 &. \\
& $\mathrm{~N}$ & 32 & 32 \\
\hline
\end{tabular}

\section{PEMBAHASAN}

Lower Urinary Tract Symptoms atau yang biasa dikenal sebagai LUTS merupakan masalah umum, terutama bagi pria usia lanjut. ${ }^{9}$ Telah dilaporkan bahwa $90 \%$ dari pria yang berusia 50 sampai 80 tahun menderita LUTS. ${ }^{6}$ Usia merupakan faktor resiko terbesar untuk presentasi LUTS, dan hiperplasia prostat jinak adalah salah satu penyebab paling umum dari LUTS. Diperkirakan bahwa 50\% dari pria di atas usia 60 tahun memiliki gejala hiperplasia prostat sehingga dapat mempengaruhi kualitas hidup penderita. ${ }^{13}$

Beberapa instrumen telah dikembangkan untuk menilai derajat keparahan gejala LUTS, dan secara global kuesioner IPSS adalah salah satu instrumen yang paling sering digunakan. ${ }^{14}$
Pada penelitian yang dilakukan pada bulan November-Desember 2015,dibeberapa Puskesmas Kota Manado, didapatkan 32 penderita yang bersedia menjadi responden. Dari 32 penderita ini, didapatkan bahwa golongan usia terbanyak berada pada kisaran antara usia 60-69 tahun, yakni sebanyak 10 penderita (31,3\%) dan yang terendah pada umur $\geq 91$ tahun, yakni 1 penderita $(3,1 \%)$. Hasil ini tidak jauh berbeda dari hasil penelitian yang dilakukan di RS Dr. Kariadi, RS Roemani dan RSI Sultan Agung didapatkan hasil yang sama dengan RS Haji Adam Malik dan RS Pringadi Medan, yakni golongan usia paling banyak berada pada usia 60-69 tahun sebesar $32,7 \%{ }^{15}$ 
Selanjutnya, penderita diberikan kuisioner IPSS yakni, sistem skoring yang diambil dari American Urological Association (AUA) yang direkomendasikan WHO untuk menilai derajat berat-ringannya gejala yang dirasakan penderita. ${ }^{4}$ Kuisioner IPSS terdiri atas tujuh pertanyaan yang berhubungan dengan keluhan miksi dan satu pertanyaan yang berhubungan dengan kualitas hidup penderita dan tiap gejalanya diberi skor antara 0-5. Hasil skor ini dapat menentukan apakah penderita berada pada derajat IPSS ringan, derajat IPSS sedang atau derajat IPSS berat. ${ }^{3,12}$ IPSS sering digunakan sebagai ukuran standar emas dalam studi klinis untuk mengevaluasi prevalensi LUTS dan hiperplasia prostat jinak dan juga untuk menilai efek dari terapi farmakologi, invasif minimal, dan terapi pembedahan untuk LUTS.

Distribusi frekuensi penderita LUTS berdasarkan gejala yang dirasakan oleh tiap penderita bervariasi, hingga didapatkan bahwa dari 32 penderita 14 diantaranya derajat IPSS berat (43,75\%) dengan skor IPSS berkisar 20-35, diikuti 14 penderita derajat IPSS yang sedang (43,75\%) dengan skor IPSS berkisar antara 8-19, dan kedua derajat ini adalah sama banyak. Hasil ini sedikit berbeda dengan penelitian yang dilakukan oleh Nugroho pada tahun 2012 menunjukkan yang paling sering dialami oleh penderita LUTS adalah derajat IPSS berat, sebesar 56\%. Penelitian yang sama juga dilakukan di Semarang pada penderita LUTS usia > 40 tahun didapati $88 \%$ IPSS derajat ringan dan 12\% IPSS derajat sedang. ${ }^{16}$

Jarang ditemukan penderita yang datang berobat dan mencari pertolongan medis disaat gejala yang dirasakan sudah cukup menganggu, sehingga didapatkan penderita LUTS sudah berada pada derajat IPSS sedang maupun berat.

Pada kuesioner IPSS dapat ditemukan satu pertanyaan tambahan yang berhubungan dengan kualitas hidup penderita, yakni skor kualitas hidup. Skor kualitas hidup terdiri atas enam kemungkinan jawaban, hal ini untuk menilai efek ketidak-nyamanan yang dirasakan oleh penderita yang mengalami LUTS. Aspek kualitas hidup penderita merupakan komponen penilaian yang juga penting untuk menilai efek keseluruhan klinis dari penderita LUTS.

Distribusi penderita berdasarkan skor kualitas hidup menunjukkan bahwa 14 penderita $(43,8 \%)$ merasa tidak nyaman dengan kualitas hidupnya, diikuti dengan 6 penderita (18,8\%) yang merasa kualitas hidupnya buruk sekali. Hasil yang berbeda diperoleh pada penelitian yang dilakukan di RSUD Arifin Achmad 58,3\% dari semua penderita hiperplasia prostat jinak dengan gejala LUTS yang berpartisipasi menyatakan tidak puas dengan kualitas hidupnya. ${ }^{17}$

Penderita LUTS biasanya mencari pengobatan medis pada saat dirinya merasa bahwa gejala yang dirasakan sudah cukup mengganggu aktivitas sehari-hari atau dengan kata lain, mengganggu kualitas hidupnya. ${ }^{13}$ Menurut Nugroho (2007) hal ini dikarenakan persepsi atas gejala yang dirasakan cukup berbeda-beda. Menurut Chapple, faktor-faktor seperti pengetahuan akan penyakit hiperplasia prostat jinak, status ekonomi, sosial budaya dari masingmasing negara yang berbeda mampu mempengaruhi penderita dalam merespon gejala yang dirasakan dan keinginan untuk berobat ke petugas medis.

Pertanyaan pada skor kualitas hidup yang telah dimasukkan oleh Komite Konsensus Internasional berguna membantu tenaga medis untuk menentukan langkah pengobatan selanjutnya.,12

Oleh karena skor IPSS dan skor kualitas hidup digunakan untuk menentukan apakah LUTS yang dinilai dengan IPSS tersebut mempengaruhi kualitas hidup dan langkah pengobatan selanjutnya, maka dilakukan uji hipotesis hubungan antara skor IPSS dengan skor dari indeks kualitas hidup menggunakan uji Rank Spearman. Didapatkan bahwa korelasi signifikan $(\mathrm{p}=0,001$ atau $\mathrm{p}<$ 0,005 ) dengan nilai korelasi sebesar 0,578 
maka penelitian ini menemukan bahwa terdapat hubungan yang bermakna antara skor IPSS dengan skor kualitas hidup. Hasil yang sama juga diperoleh dari penelitian yang dilakukan oleh Agwal, $d k k$ di Nepal (2008) menunjukkan bahwa terdapat hubungan yang signifikan antara skor IPSS dengan kualitas hidup penderita LUTS $(p=0,001) .{ }^{19}$ Hasil yang sama juga ditemukan pada penelitian yang dilakukan di Jeju, Korea (2012), bahwa korelasi IPSS dengan kualitas hidup dinilai cukup berhubungan, dan secara statistik memiliki korelasi yang bermakna. ${ }^{20}$

Hal ini menunjukkan bahwa memang sebagian orang datang mencari pengobatan medis disebabkan oleh derajat gejala yang dirasakan sudah cukup mengganggu kualitas hidup. ${ }^{3}$ Khususnya di Manado sendiri, kebanyakan penderita LUTS datang berobat pada saat sudah masuk dalam derajat sedang maupun berat, dan diikuti dengan perasaan yang tidak nyaman.

Berdasarkan data yang diperoleh dari penelitian yang dilakukan di beberapa Puskesmas Kota Manado, diketahui bahwa hampir sebagian besar penderita memiliki pendidikan rendah dan berpenghasilan ekonomi dibawah rata-rata.

Keadaan seperti ini serupa dengan pendapat Nugroho (2002) bahwa keterlambatan deteksi dini dipengaruhi oleh persepsi penderita terhadap keluhan yang dirasakan. Selain itu, menurut Purnomo (2012) dapat pula disebabkan oleh banyak faktor, antara lain faktor pendidikan, pengetahuan, ekonomi, dan sosial budaya. ${ }^{12}$

\section{KESIMPULAN}

Berdasarkan hasil penelitian pada penderita LUTS dibeberapa Puskesmas Kota Manado pada bulan NovemberDesember 2015 disimpulkan bahwa adanya hubungan yang bermakna $(\mathrm{p}=0,001$ atau $\mathrm{p}<0,005)$ antara skor IPSS dengan kualitas hidup penderita LUTS melalui uji korelasi Rank Spearman dengan nilai $\mathrm{r}=$ 0,578 .
Faktor yang menjadi alasan mengapa penderita LUTS datang berobat pada saat sudah masuk derajat sedang maupun berat, dan kualitas hidup tidak nyaman oleh karena pendidikan yang rendah dan berpenghasilan ekonomi di bawah rata-rata.

\section{SARAN}

Berdasarkan hasil penelitian yang telah dilakukan, maka peneliti menyarankan hal terkait penelitian yakni pria yang berusia di atas 40 tahun jika terdapat keluhan Lower Urinary Tract Symptoms (LUTS) seperti tidak mampu menahan miksi, sering terbangun malam untuk miksi, frekuensi miksi tidak normal, pancaran miksi yang lemah, miksi yang terputus-putus, perasaan tidak puas setelah miksi, mengejan saat memulai miksi, disarankan untuk segera memeriksakan dirinya ke dokter atau rumah sakit daerah setempat agar penyakit tidak semakin bertambah parah dan dapat meningkatkan kualitas hidup yang lebih baik.

\section{DAFTAR PUSTAKA}

1. Rosenberg MT, Staskin D, Kaplan SA, et al. A practical guide to the evaluation and treatment of male lower urinary tract symptoms in the primary care setting. Int J Clin Pract CME. 2007; 61(9):[1p].

2. Grummet J, Wittert G. Lower Urinary Tract Symptoms (LUTS) in men. Andrology Australia Factsheet, 2014; 12):[1p].

3. Kapoor A. Benign prostatic hyperplasia (BPH) management in the primary care setting. Can J Urol. 2012; 19(Suppl 1):[1p].

4. Parsons KJ. Benign prostatic hyperplasia and male lower urinary tract symptoms: epidemiology and risk factor. Curr Bladder Dysfunct Rep. 2010 Dec;5(4):212-18.

5. Rodrigues $P$, Hering $F$. P., Campagnari J. C. Impact of urodynamic learning on the 
management of benign prostate hyperplasia issue. Canada: Canadian Medical Journal.2008

6. Rosette JD, Alivizatos G, Madersbacher S, et al. Guidelines on benign prostatic hyperplasia. European Association of Urology. 2006; 5[1p].

7. Fadlol, Mochtar. Prediksi volume prostat pada penderita pembesaran prostat jinak. Ind J of Surg. 2005; 33-4: 139-45.

8. Suryawisesa, Malawat, Bustan. Hubungan faktor geografis terhadap skor gejala prostat internasional (IPSS) pada komunitas suku makassar usia lanjut tahun 1998. Ropansuri. 1998; 26: $1-10$

9. Arinayagam $M$, Arinayagam $R$, Rashid P. Lower urinary tract symptoms-current management in older men. Australian Family Physician. 2011;40(10):758-67

10. Trueman P, Hood SC, Nayak US, Mrazek MF. Prevalence of lower urinary tract symptoms and selfreported diagnosed benign prostatic hyperplasia and their evect on quality of life in a communitybased survey of men in the UK. BJU International 1999; 83: 41015.

11. Spatafora $S$, Casarico A, Fandella A, Galetti C, Hurle R, Mazzini E, et al. Evidence based guidelines for the treatment of lower urinary tract symptoms related to uncomplicated benign prostatic hyperplasia in Italy: updated summary from AURO.it. Ther Adv Urol. 2012; 4(6): 279.

12. Purnomo B. Dasar-dasar urologi. Ed 3. Jakarta: Sagung Seto; 2012. H. 122-3.

13. Claus RG. Benign prostatic hyperplasia: an overview. University of Texas southwestern medical center. Dallas, Tx,2005.
14. Barkin J. Benign prostatic hyperplasia and lower urinary tract symptoms : evidence and approaches for best case management. Can J Urol. 2011; 18(Suppl 1):[14p].

15. Sinaga UM, B Harry, L Aznan. Majalah Kedokteran Nusantara. Vol 39; September 2006

16. Nugroho A, Muslim R. Pengaruh faktor sosiodemografi terhadap IPSS pada laki-laki sehat penduduk desa dan kota. Bag. Ilmu Bedah FK UNDIP/RSUP Dr Kariadi Semarang. 2000.

17. Fitriana N, Zuhirman, Suyanto. Hubungan benign prostate hypertrophy dengan disfungsi ereksi di RSUD Arifin Achmad Provinsi Riau. Riau. Fakutltas Kedokteran Universitas Riau; Januari 2014.

18. Chapple C, Abrams P. Male Lower Urinary Tract Symptoms (LUTS). An International Consultation on Male LUTS. Société International d'Urologie; 2013

19. Agwal CS, Chalise PR, Bhandari BB. Correlation of prostate volume with international prostat symptom scrore and quality of life in men with benign prostatic hyperplasia. Nepal Med Coll J 2008; (10)2: 1047

20. Huh Jung-Sik, Kim Yoong-Joo, Kim Sung Dae. Prevelance of Benign Prostatic Hyperplasia on Jeju Island : Analysis from a Crosssectional community based survey jeju international university. 